\title{
Positioning Excellence - Based Model of Business Performance Supported by Market Orientation and Organization Innovation Among The Small and Medium Scale in Binong Jati Knitting Enterprices, Bandung
}

\author{
EDDY SOERYANTO SOEGOTO
}

\author{
Indonesia Computer University, Bandung 40132, Indonesia \\ Email correspondence: ssoegotoeddy@gmail.com
}

\begin{abstract}
To keep sustaining in the high competition, the small and medium scale enterprises (SME) must be able to know the customer's needs and wants. The SME having the market orientation will completely fulfill what the customers want considering that market orientation is the commitment of the SME business actors to give the additional values for the customers. It is demanded to support the organization innovation in order that it can create the positioning excellence of the enterprise expected to determine the business performance. The goal of the research is to test a business performance model by taking into account the positioning excellence supported by market orientation and organization innovation. The method used in this research is descriptive and explanatory method, using the craftsmen in Binong Jati Knitting Centre as the research sample consisting of 203 craftsmen. The statistical analysis used was serqual Equation Model with Lisrel 8,7 program. The result of the research shows that in the operation the business actors of Binong Jati Knitting SME pay little concern toward the market orientation in conducting their business; the business actors in general have not owned the innovative enterprises shown by the product innovation and the innovation in management process; the business actors have been able to place their e-Business in the high positioning excellence. Meanwhile, the business performance of Binong Jati Knitting SME is not proper yet especially in the point of sales, profits, and market share achieved; the positioning excellence is influenced significantly positive by the market orientation and organization innovation. In the effort to improve the business performance, SME is recommended to implement the model simultaneously.
\end{abstract}

Key words: Market Orientation, Organization Innovation, Positioning Excellence, Business Performance.

\section{Keunggulan Posisi- Berdasarkan Model Kinerja Bisnis Didukung oleh Orientasi pasar dan Inovasi Organisasi Diantara Perusahaan Skala Kecil dan Menengah Di Binong Jati Pengusaha Rajutan, Bandung}

\begin{abstract}
Abstrak
Untuk menjaga mempertahankan dalam kompetisi yang tinggi, perusahaan-perusahaan skala kecil dan menengah (UKM) harus dapat mengetahui kebutuhan pelanggan dan keinginan. UKM memiliki orientasi pasar benar-benar akan memenuhi apa yang pelanggan ingin mengingat orientasi pasar adalah komitmen dari pelaku usaha UKM untuk memberikan nilai tambah bagi pelanggan. Hal ini menuntut untuk mendukung inovasi organisasi agar dapat menciptakan keunggulan posisi perusahaan diharapkan untuk menentukan kinerja bisnis. Tujuan dari penelitian ini adalah untuk menguji model kinerja bisnis dengan memperhatikan keunggulan posisi didukung oleh orientasi pasar dan inovasi organisasi. Metode yang digunakan dalam penelitian ini adalah metode deskriptif dan menjelasakan, menggunakan pengrajin di Binong Jati Pusat Rajutan sebagai sampel penelitian yang terdiri dari 203 pengrajin. Analisis statistik yang digunakan adalah serqual Model Persamaan dengan Lisrel 8,7 Program. Hasil penelitian menunjukkan bahwa dalam operasi pelaku usaha dari Binong UKM Rajutan membayar sedikit perhatian terhadap orientasi pasar dalam menjalankan usahanya; pelaku usaha pada umumnya belum dimiliki perusahaan inovatif yang ditunjukkan oleh inovasi produk dan inovasi dalam proses manajemen; pelaku usaha telah mampu menempatkan e-Bisnis dalam keunggulan posisi tinggi. Sementara itu, kinerja bisnis Binong Jati Knitting UKM tidak tepat belum terutama di titik penjualan, laba, dan pangsa pasar mencapai; keunggulan posisi dipengaruhi positif secara signifikan dengan orientasi pasar dan inovasi organisasi. Dalam upaya meningkatkan kinerja bisnis, UKM dianjurkan untuk menerapkan model secara bersamaan.
\end{abstract}

Kata kunci: Orientasi Pasar, Inovasi Organisasi, Keunggulan Posisi, Kinerja Bisnis. 


\section{INTRODUCTION}

On this competitive era the needs of organizations to improve the attention of their customers, encourage them to achieve goals through customer as a focus on the orientation of the organizations. Even though technology is able to create the customer attention, service is a 'human' matter. How an individual is inspired, capable of doing his/her job, motivated, and recognized by his/her leaders and managers because of his/her skills are the keys to construct an enterprise that is oriented to customers.

The employees' capability in giving a good service to his/her customer is influenced by an internal condition of the organization. If the company wants their employee Wants to serve their customers well then the company should serve them better (George, 1990). The way of customer service affected by the internal organization (Hee et. al., 2001) internal reciprocal relationship between employee and organization should be effective and efficient first before the success of external relation between employee and the customers. The way you (a management) treat your employees is a reflection of how your employees give service to your customers. (Jenny et.all, 1996). So the company's internal service is really important during determination of company success.

Bandung as a fashion creative industry has a potency to develop the clothing industries. A knitwear company is one of the developing industries there. A small and medium industry on Binong Jati, The Centre Knit Bandung industry is a small industry which can potentially contribute to Bandung city's economy. Its products are able to compete with other knitwear products from bigger industries. Besides offering relatively low prices, the mode of clothes sold there is also up to date, based on market's taste. Offering its customers with various patterns of knitwear, Binong Jati Knit products are widely known.

The power of creative industry are design, the material diversity, brand specificity, and uniqueness. The success of creative industry depends on the availability of textile industry and the distributor such as Factory Outlet. But there is a decline of industrial quantities in Bandung by $80 \%$ compared to three years earlier based on Indonesia Business Associations West Java data. Binong Jati Knit industries were established on 60 's and still potentially move the economic society.

The business performance on Binong Jati Knit industries is affected by the imported product from China and Korea as competitor which are cheaper so that consumers prefer the imported product. So it resulted the reduced of profit level even some craftsmen are forced to stop their production. Various problems faced by small industry caused less performance even failure of the business. The absence of the next generation of craftsmen in Binong Jati is because the people prefer their children to work in other place which is better than knitting industry. Currently, the craftsmen obstacle is to market their product. This is because some craftsmen still use the same marketing techniques as before and they also led to lack of knowledge and skills in marketing aspects so they failed to achieve their target. The production capacity of knitting in Binong Jati knit industries continued to decline. In 2012, the production was increased about $2 \%$ and produced 984.426 dozen a year, but in 2013 it was decline about $10 \%$ and only 885.983 dozen a year. In 2014 the production capacity was decreased about 5\% from 2013 and only able to produce 841.683 dozen a year. This condition causes the level of business profit which impacted to the employer shutdowns.

Table 1 Number of Craftsmen and Industry Business of Knitted Centre Binong Jati Bandung 2010-2014

\begin{tabular}{ccc}
\hline Year & Number of Craftsmen & Business unit \\
\hline 2010 & 3,120 & 390 \\
2011 & 2,115 & 350 \\
2012 & 2143 & 293 \\
2013 & 2036 & 264 \\
2014 & 2033 & 264 \\
\hline
\end{tabular}

Source: 2010-201 Disperindag 4, Cooperative Knitted Binong Jati 2014

Table 1 indicates the decrease of business performance and the number of craftsmen direct impact to the low capacity of production in the Binong Jati knitting industry. Those occur due to lack of knowledge and education of entrepreneurs to innovate their product, this condition happens because they always emphasize only on their ingredients quality. The evaluation result indicates 
that the decrease of business performance is caused by lack of knowledge about marketing strategy such as market orientation and product innovation and positioning of product advantages. Employers mostly have low education levels and use conventional way during both manufacturing and marketing process that affect the business performance.

Various efforts have been made to improve the business performance of Binong Jati knitting industries, which always test the standardization of production, and product innovation. The product innovation such as combining the knitwear with batik cloth, making knitted shoes, bags, pants and accessories made from knitted. combining the knitwear with batik cloth, making knitted shoes, bags, pants and accessories. Then the Binong Jati products are weak competitors to Chinese and Korean products. This is a result of a slow economic growth of Indonesia, because the domestic market is flooded with imported products due to the effectuation of free trade ACFTA (ASEAN China Free Trade Agreement). These issues should be immediately managed because it will threaten and hinder the development of the company. Market orientation is a business that makes the customer's perspective as a reference point the company's total operations. A business is a market-oriented if cultures are systematically and fully committed to the continuous creation for superior customer value. Fundamentally, achieving a market orientation involves the use of superior organizational skills in understanding and satisfying customers.

(Barnes (2000) states that high competition results the company to be selected by the nature of competition, the winning is to take advantage of opportunities and use its resources optimally. Furthermore, it is also stated that the business is able to develop quickly if it has a strong market orientation (Best, 2005). Market orientation developed within an organization will be significant resources to maintain the business positional advantage. Thus, a market-oriented company chooses a target market that is more discreet and offers a total of better and adapted to the preferences of customers. The market oriented is very important in ensuring the company, which increases global competition and the changing customer's needs requires companies to always be able to adapt to market changes. Market orientation has close links with the company's innovation capabilities. Marketoriented company will always be willing to meet changing market demand. To meet the changing wants and needs of the market, employers can reach their goals through the company innovations. And these innovation can be made through the innovation in inputs, processes and end products. The organizational innovation and market orientation have a strong relationship in shaping the company's performance (Lado and Albert, 2001) said that.

Furthermore, innovation is a key element of the success of an entrepreneur (Ross et.al, 2007). Company market-oriented means that the company is constantly an activity that aims to meet the needs and desires of the target market. The company orientations are always oriented to needs and wants of target markets, and will create an excellent position in the eyes of the customer industry competition. Increased market share will create profits for the company, and ultimately company performance will also increase.

Companies with high innovation performance will always Make an innovative product or act their pursuant service to better changes in steel-material wholeness matter and in the matter of the desires of customers, thereby increasing the advantages of company positioning, which in turn would increase the company's performance (Yamin, 2007). (Low et.al, 2007) the product innovations related to increased market share. SMEs that have high organizational innovation will be able to compete by raising new things that are not owned by other companies. As disclosed by Neely et.al (2001) that "organizations that perform continuous innovation will be more likely to survive in the competition".

Therefore, Researchers' aims are to test whether there is a linkage between Market orientation and Innovation organization with Excellence positioning and Business Performance, and to test Business Performance models built through Excellence positioning, Market Orientation and Organizational Innovation.

\section{LITERATURE REVIEW}

To have a positional advantage, which is more superior 
JURNAL BISNIS \& MANAJEMEN

ISSN 1412 - 3681

than the other competitor isn't easy. To identify the advantages owned and compared with the competitor, the company needs to understand the pattern of existing competition and the company's position in the competition. The marketing strategy selected should be able to empower the resources or internal strength of the organization. This internal strength of the organization is optimal in responding to external threats and opportunities. This is reasonable because marketing is a function which directly determines sales and activity that has wide coverage for not only include internal activities but also externally (Best, 2005), (Sucherly, 1996). Positional advantages of a business to its competitors, will largely depend on the ability of institutions to create a unique and superior position in the minds of stakeholders including consumers. (Fisk, 2006) The positional excellence exists in strategy and it a source of business success. (Gray and Hooley, 2002) states the marketing concept of strategic emerging in the face of market conditions that are volatile, is a market-based management, market driven strategy, and market orientation. The concept of market-based and market driven is included in the framework of a strategy of marketoriented include: company $\left(C_{1}\right)$, customer $\left(C_{2}\right)$ and competitors $\left(\mathrm{C}_{3^{\prime}}\right)$ and strive to provide superior value to its customers to achieve positional advantage in the global market, because the main orientation is to improve market access. Pulendran, et al. (2000) states through market orientation or to be market driven, the company will acquire rapid market information, real-time, accurate, and oriented action as an attempt to generate the sustainable competitive advantage / Superior Competitive Advantage (SCA) through the presentation of superior value for customers / Superior Customer Value (SCV).

Both Day and Wensley (1988) and Bharadwaj et al. (1993) using the framework that reflects the views Porter (1985) concerning the positional advantage (positional advantage) in connection with the use of the term and cost leadership or differentiation. The dichotomy view of positional superiority is challenged by Booth and Philip (1998) proposed that organizations need to be more flexible and cost leadership and differentiation combine to offer a unique value to its customers.

Slater and Narver (2000) state that customers continue to increase the level of demand for quality and services at lower cost low. Day and Wensley (1988) state forms different from the difference excellence positional concerning the brand name, the characteristics of innovative and quality products that are superior are offered to potential customers to maintain market position which will lead to the leadership of the superior financial performance.

Research conducted by Agarwal et.al (2003) using an approach shows that innovation and market orientation as a synergy of companies are able to increase the company's market share. The shape of the relationship between the oriented market and innovation is shown in the form of two-way casual relationship or equivalent. The better oriented the better they will likewise organizational innovation and vice versa. These two variables would be a good synergy for creating excellence positioning of the company. Some experts have a lot of digging linkage between the markets oriented with business performance, obtaining the results that the market orientation has a significant influence on several measures of the performance of new products (Atuahene-Gima, 1996). This shows that companies Which are market oriented will be able to create new products that can be accepted by customers that are superior consumer value.

SME as an organization needs an organizational innovation. So far, SME is considered as the most flexible organization in running operations. This means that SME will have high organizational innovation. SME that has a high organizational innovation will be able to compete by raising new things that are not owned by other companies. With the ability to create excellence positioning then the company can obtain a larger portion of sales, and ultimately impact on the business performance of SMEs. The organizations which perform continuous innovation will be more likely to survive in the competition (Neely et.al, 2001). Based on those opinions above, companies are able to achieve a breakthrough in the organization through input, process, and output and will be able to have an edge positioning of their products and in the end, there is an increase of company profit. Market orientation The market orientation strongly focuses on the customer focus that also includes the orientation of a strong competitor and a team 
approach that is strong to build solutions for customers (Best, 2005). thus the end result will be an increase in corporate excellence. And organizations that perform continuous innovation will be more likely to survive in the competition (Neely et.al, 2001).

Small and medium enterprises basically have access to the targeted market. The customers' needs and desires of the market will be very easy to detect in this kind of enterprise. With these advantages With these advantages, employers should understand their medium and small companies' needs and desires of the targeted market so that they will be able to take the advantage of positioning as a strategy to compete with other companies. SMEs which applied the market orientation will be more competitive to the market through its ability to understand the market, so It creates products which are ore affordable because it always focuses on the targeted customers, pays attention to existing competitors and strives to maximize its profit. With the market-oriented sales will increase which in turn will also increase the performance of SMEs. Companies that have a high innovation performance will always create a product or service that is in accordance with the changing needs and desires of the customer. This will have an impact on advantages of positioning the company which is also increasing the superior value and the corresponding consumer price level so that the company's performance will increase. The study on a manufacturing company in Australia Gets result that there is a relationship between innovation companies and the company's performance (Yamin et.al, 2007). Based on the literature review, It can be described that Research Model Framework is presented in Figure 1. below.

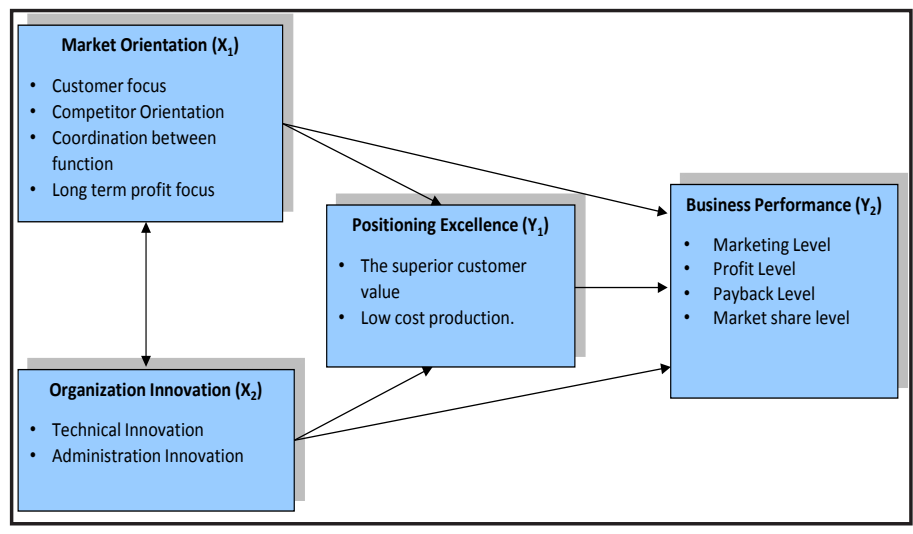

Figure 1 Research model framework

\section{METHOD}

The methods used are descriptive method and explanatory research method. These methods are used to test the increase of work performance through customer-based focus marketing, positioning preminence, market orientation, and organisational innovation. This research is done by using survey method (Churchill and lacobucci, 2005:79).

The research objects are business owners in knitting industry in Binong Jati Knitting Industries Bandung, with 203 business persons as samples. This research uses a random-sampling method that can generate the numbers of the data analysis. The validity test shows that the measuring tools parameter is valid. The statement point is tested to be valid since the correlation of the coefficient is $\geq 0.30$ (Barker et al., 2002:70). Next step shows that reliability test by using split-half method is reliable since the coeeficiency is $\geq 0,70$ (Barker et al., 2002:70).

The descriptive analysis are based on the Cooper and Schindler $(2006$; 467) which shows that the first quartile is the 25th percentile, second quartile (median) is the 50th percentile, and third quartile is the 75th percentile. Based on the questionnaire that use scale 1-5, the first quartile is $1-2$ to show poor $(<2)$, second quartile $=2-3$ category less than $(>=2)$, third quartile $=3-4$ category suffice $(>=3)$ and fourth quartile $=4-5$ category decent $(>=4)$.

The next analysis step is to test the hypotheses by using Structural Equation Modeling (SEM). This method is a statistical technique that intends to analyze latent indicator and inaccuracies (Joreskog \& Sorbon, 1996 in Achmad Bacrudin dan Harapan L. Tobing (2003). The analysis by latent variable relations with another latent variable is known as structural equation that together can result in mistakes during the measurement process. Another point by Sem is this technique can analyse reciprocal relations.

\section{HYPOTHETICAL TESTING}

\section{First hypothesis}

$\mathrm{HO}: \gamma_{1.1}, \gamma_{1.2}, \beta_{1.1}=0$ : Bargaining position ( $\eta 1$ ) is not affected by market orientation (६1) and organisational innovation ( $(2)$ 
JURNAL BISNIS \& MANAJEMEN

ISSN 1412 - 3681

$\mathrm{H} 0: \gamma_{1.1}, \gamma_{1.2}, \beta_{1.1} \neq 0$ : Bargaining position (n1) affected by market orientation ( $(\xi 1)$ and organisational innovation (६2)

\section{Second hypothesis}

$\mathrm{H} 0: \gamma_{1.1}, \gamma_{1.2}, \beta_{1.1}, \beta_{2.1}=0$ : Workperformance $(n 2)$ is not affected by bargaining position ( 1 1) market orientation (६1) and organisational innovatiion (६2) neither simultaneously norpartial

$H 1: \gamma_{1.1}, \gamma_{1.2}, \beta_{1.1} \beta_{2.1} \neq 0$ : Work performance $(n 2)$ is affected by bargaining position (n1) market orientation (₹1) and organisational innovatiion (६2) neither simultaneously norpartial

To test the partial hypotesis, author use " $\mathrm{t}$ " test with formula:

$$
t=\frac{\hat{\gamma}_{3 i}}{S E\left(\hat{\gamma}_{3 i}\right)}
$$

To test the simulatneous hypotesis, author use $\mathrm{F}$ test with formula:

$$
\begin{aligned}
F= & \frac{R^{2} / K}{\left(1-R^{2}\right) /(N-K-1)}
\end{aligned}
$$

\section{Test criteria}

Reject null hypothesis if $\mathrm{F}_{\text {count }}$ higher than $\mathrm{F}_{\text {table }}$ in significancy test of $5 \%$

\section{RESULT AND DISCUSSION}

The increase of efficiency and work effectivity that driven through organisational innovation needs market strategy that focuses on planned sustainability of consumer based orientation, that will assure the bargaining position thus the work performance will increase, align with the company's goal.
Jurnal Bisnis \& Manajemen, 2016, Vol. XVII, No. 1, 22-32

Table 2 Percentage of scoring criteria based on respondents response from each question items

\begin{tabular}{ccc}
\hline No. & \% Score number & Perception criteria \\
\hline 1 & $20.00-36.00$ & Worst/never \\
2 & $36.01-52.00$ & Poor/ Almost never \\
3 & $52.01-68.00$ & Less/ Sometimes \\
4 & $68.01-84.00$ & Good/ Often \\
5 & $84.01-100$ & Very Good/ Always \\
\hline Note: baseline 20\% generated from 1/5 and top line 100\% from \\
5/5
\end{tabular}

Table 3 Response from perception of business owners from each measured research variables

\begin{tabular}{ccccc}
\hline $\begin{array}{c}\text { Statement } \\
\text { points }\end{array}$ & Actual score & Ideal score & \% actual score & Criteria \\
\hline $\begin{array}{c}\text { Market } \\
\text { orientation }\end{array}$ & 5498 & 8120 & $67.71 \%$ & Less \\
$\begin{array}{c}\text { Organisational } \\
\text { innovation }\end{array}$ & 4114 & 6090 & $67,55 \%$ & Less \\
$\begin{array}{c}\text { Bargaining } \\
\text { position } \\
\quad \text { Work }\end{array}$ & 4270 & 6090 & $70,11 \%$ & Good \\
performance & 5460 & 8120 & $67.24 \%$ & Less \\
\hline
\end{tabular}

The research is resulted in market orientation in Small and Medium Eenterprises of Knit in Binong Jati, which shows that their lack of market orientation has not focused on consumer-based. They have not had a competitive view that results to the strength and weaknesses mapping. The coordination within each functions has not been optimized thus this results in having the long-term of awareness to keep the relations with their customers well, because it is still in the verge of getting profit based on short-term receivable.

The IKM has not yet had the ability to develop unique product design and still has the limitation to acquire cheap resources. Even though the IKM has the ability to develop product variation, it is still limited. The IKM ability to adopt new production method is still very low. The process of the innovation is still not yet considered to be capable of arranging new strategy and innovation in administration scheme. Nevertheless, the IKM already has the flexibility in allocating its budget.Bargaining position of these businessowners in creating superior consumer value with a relatively low budget is described through a well hierarchy. This shows that IKM Knitting Binong Jati Bandung has been able to create a bargaining 
position. Moreover the overall work performance is considered that it has not been able to achieve the desirable target, whether in capital growth, market share, profit, and generated income.

The statistic testing is shown in this Figure 2.

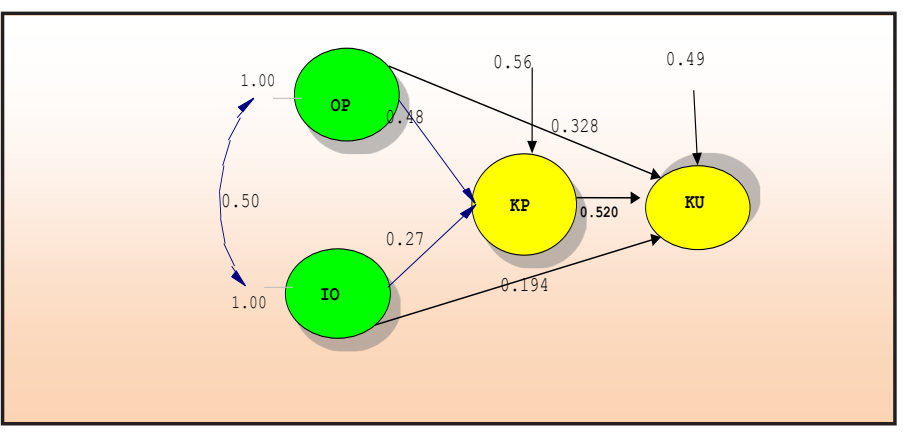

Figure 2 Statistical Testing

Based on the analysis on the above picture, we may see that the market orientation and organisational innovation have a positive correlation and significant with the number of 0.5 . It means that everytime market-orientation changes happen, they will be followed by changes in organisational innovation as high as $50 \%$. The number of the direct variables of market orientation on bargaining position is $23.04 \%$. The number of the direct variables of organisational innovation on bargaining position is $13.77 \%$. this means that every 100 per cent of variables of market orientation will strenghten the capability in variable organisational innovation around $23.04 \%$, and every increase of 100 per cent in organisational innovation will also increase the variable of bargaining position of $13.77 \%$. The high number of simultaneous variable of the market orientation and organisational compared to bargaining position is $43.2 \%$, thus another variables bargaining psotion that being measured are $56.71 \%$.

Based on the statistics analysis, the number of variable of market orientation to the work performance is $10.75 \%$. The direct variable of irganisational innovation compared to work performance is $3.76 \%$. Thus it is shown that the increase of every 100 per cent in variable of market orientation, will also incur to the organisational innovation around $10.75 \%$, and every $10.75 \%$ in organisational innovation will lead to increasement of work performance of $20.87 \%$, and then the factor outside these variables will influence the bargaining position around $79.13 \%$. The variable of bargaining position variable compared to work performance is around $27.04 \%$. This shows that every 1 per cent increase in bargainig postion will lead to work performance of $27.04 \%$.

To test the significaces, the $f$ test and t test are conducted. The Lisrel output shows that value of fcount and t-count of each variables is bigger than f-table and t-table

Hypothesis 1:

\begin{tabular}{ccccc}
\hline $\mathbf{R}^{2}$ & $\mathbf{F}_{\text {-count }}$ & $\mathbf{F}_{\text {-table (db: 2;201) }}$ & $\mathbf{H o}_{1}$ & $\mathbf{H a}_{\mathbf{1}}$ \\
\hline 0,4329 & 23,06 & 2,370 & Rejected & Approved \\
\hline
\end{tabular}

He hypothesis show that simultaneously, market orientation and organisational innovation have a positive and significant impact to barganing position. This means that variables of market orientation and organisational innovation can determine changes to bargaining position of $43.29 \%$ and the rest of $56,71 \%$ are influenced by other factors.

This research may support the research done by Lado and Albert (2001), Low at.al (2007), and Agarwal et.al (2003) that shows significant relations between market orientation and organizational innovation. Moreover Craven (2006) interposes that a marketoriented company needs a full support of strengths. The organisation has to monitor changes in needs, and decide the factors that will comprise the effects that will totally affect the customer satisfaction, increase the product innovation, and implement strategies to build organizational competitiveness.

\begin{tabular}{ccccc}
\hline Coefficiency & $\mathbf{t}_{\text {-count }}$ & $\mathbf{t}_{\text {-table (db:201) }}$ & $\mathbf{H o}_{\mathbf{2}}$ & $\mathbf{H a}_{\mathbf{2}}$ \\
\hline 0,4831 & 7,8225 & 1,9718 & Rejected & Approved \\
0,2727 & 4,0185 & 1,9718 & Rejected & Approved \\
\hline
\end{tabular}

Next, the test shows that partially there are psotive and significances shown from variable of market orientation ( $(1)$ to positioning $(\eta 1)$ and organisational innovation to bargaining position of small business enterpresis of knit in Sentra Industri Binong Jati Bandung.

These results are aligned with what has been stated by Best (2005:24), that a powerful market orientation of customer-based driven will also focus on market competitiveness and also a powerful team approach 


\section{JURNAL BISNIS \& MANAJEMEN}

ISSN 1412 - 3681

to create solution for their customers. Thus, that will lead to strenghthen the market power. Neely et.al (2001:114) shows that an organisation that always keeps making innovation will survive in the competition

Hypothesis 2:

\begin{tabular}{ccccc}
\hline $\mathbf{R}^{2}$ & $\mathbf{F}_{\text {-count }}$ & $\mathbf{F}_{\text {-tabel(db: 2;01) }}$ & $\mathbf{H o}_{1}$ & $\mathbf{H a}_{1}$ \\
\hline 0,2087 & 4,74 & 2,370 & Rejected & Approved \\
\hline
\end{tabular}

The hypothesis has proven that market orientation

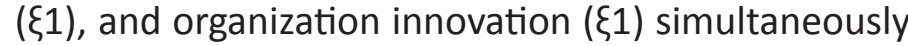
influencing positively and significantly to work performance (n2) in Industri Kecil Menengah Rajut di Sentra Industri Binong Jati Bandung. A research done by Agarwal et.al (2003) in 201 international hotel shows that innovation is an intervening that correlates market orientation with company performances. In this research, innovation is a result of company in following wants and needs of the market changes, Creating product through innovation. As company's ability to innovate is getting higher, at that point also the performance of the company will be higher.

\begin{tabular}{ccccc}
\hline Coefficient line & $\mathbf{t}_{\text {-count }}$ & $\mathbf{t}_{\text {-table (db:201) }}$ & $\mathbf{H o}_{2}$ & $\mathrm{Ha}_{2}$ \\
\hline 0,328 & 4,9225 & 1,9718 & Rejected & Accepted \\
0,194 & 2,8037 & 1,9718 & Rejected & Accepted \\
\hline
\end{tabular}

Hypothetical testing shows that there are influences that partially show significancies of the variables of market orientation ( $(1)$ to work performance $(\eta 2)$ and organizational innovation of work performance $(n 2)$ of Industri Kecil Menengah Rajut di Sentra Industri Binong Jati Bandung. These results are also completed by Ross that the result shows how innovation becomes the key to the success of an entrepreneur. A company that has an orientation to the market shows that this company also shows the effort to fulfill the needs and demands from the target market. It will also create the bargaining positions that will lead to target market of the industry competitiveness. It is also shown by Olivares and Lado (2003) that significances of influence of market orientation are through innovation and customer loyalty for business performance.

Agarwal, Errammilli and Dav (2003) in a research analyze that the influence of market orientation to work and finance of the company shows that results
Jurnal Bisnis \& Manajemen, 2016, Vol. XVII, No. 1, 22-32

of market orientation has a significant effect to corporate financial performance.

Agarwal et.al (2003) based on 201 international hotel provide results that Show innovation is an intervening variable that connects the influences of market orientation to work performance. Based on this, it can be concluded that market orientation gives a high influence both to bargaining position and work performance compared to influences Shown by an organizational innovation.

Hypothesis 3:

\begin{tabular}{ccccc}
\hline Coeeficient line & $\mathbf{t}_{\text {-count }}$ & $\mathbf{t}_{\text {-table(db:201) }}$ & $\mathbf{H o}_{\mathbf{3}}$ & $\mathbf{H a}_{\mathbf{3}}$ \\
\hline 0,520 & 8,631 & 1,9718 & Rejected & Approved \\
\hline
\end{tabular}

It shows that there are significancies based on variable of bargaining position ( $\eta 1$ ) to work performance $(\eta 2)$ in Knitting SME of Binong Jati Bandung. Powell dan Micallef (1997:375) stated: "To position a product, several pieces of information must be obtain. That is the determination of attributes that influences the customer's purchase decision."

Moreover, the hypothetical testing of the bargaining postition has a significant contribution to work performance, supported by concept model of marketing strategy (CMS). According to Brown (1997: 22-23) it shows that an integrated correlation between business strategy and marketing strategy with deepening on the creation, improvement, and strengthening companys position in market creates business value and customer value. Competitive marketing strategy concept is used for environment analysis to define competitiveness used for analyzing environment that is considered to be market oriented that is constantly changing. Hult dan Kitchen (2001:899) in their research concerning market orientation stated that resource based model in a company suggest 4 capabilities which are market orientation, entrepreneurship, innovativeness, and organizational learning that each contribute to the creation of positional advantage for 181 multinational companies in the United States.

\section{CONCLUSION}

First businessowners in SME of Knitting in Binong Jati in their operation are lack of attention on paying the 
details of market orientation, which are customer focus based, functioal coordination, and focusing only on short term profit. So, it can be concluded that this SME is not using a market orientation; the innvation within this SME is based on product innovation and innovation on process is relatively low, which can be concluded that they have not met a criteria of having innovative business unit in their product innovation and management process.; the positioning maeasured by superior customer value and low cost that is relatively low has put their position in a stratgic bargaining position. Meanwhile, the work performance is considered to be poor, considerably in profit and income on the market.

Second market orientation and Organisational innovation have a significant and relatively positive correlation. This shows that the increase in marlet orientation will also be aligned with the organisational innovation in this SME of Binong Jati.

Third market orientation and organizational innovation have a significant and positive correlation and significant to the bargaining position, both simultaneously and partially. This means that the increase in market orientation and organizational innovation will strengthen their bargaining position.

Fourth market orientation and organizational innovation are highly affecting the work performance, both simultaneously and partially. Partially, market orientation has higher influence to work performance compared to organizational innovation. This shows that the market oriented SME will have a higher bargaining position, mostly in the increase of work performance.

Fifth the result of this research shows that there might be possibilities of bargaining position to the work performance. It means that the increase of bargaining position in the SME of knitting in Binong Jati will, in general, enhance the work performance of that SME.

\section{Suggestions}

These are suggestions based on this research:

First the SME of Knitting Binong Jati should have a bargaining position, aside from their low work performance. So, they have to prioritise their program focusing on the awareness of market orientation, moreover to their competitor with their organisational experiencess.

Second to increase the work performance, it is really important to give a special interest on the implementation of market-oriented strategy by: (1) Increasing the ability of the business to generate information on their competitors. (2) Coaching on the awareness to know the strenghts and weaknesses of their competitors. (3) Teaching how they will be able to use the mapping analysis of competitorship in taking and making decisions.

Third Improvements on customer-focused dimensional, functional coordination as well as long term profit are also important to be underlined, because they will give a significant contribution to the increase of the market orientation, through: (1) Trainings to the crafter to undergo the comments and inputs from their customers. (2) Trainings on how to fulfill demands from their customers. (3) The escalation of the SME ability in getting maximum score from their customers.

Fourth the effort to increase the dimension of functional coordination can be elaborated with: (1) Trainings on how to intensify functional coordination, by creating quality control. (2) More frequent involvement of staffs in functional coordination. (3) Better information system so that the information spread can be more effective

Fifth menawhile, to increase dimension of focus on long-term profit can be done by following methods: (1) By Increasing the ability and effort of the SME to foster a long term relations with the customers. (2) By Increasing the awareness on the importance of foster well relationship with customers.

Sixth the increase can also be done through their product innovation that are being suggested to the SME in Kalimantan Tengah based on the indicator: hold trainings to UKM in order to escalate the skill to create unique products by: (1) Coach SME to find posiibilities in search of alternatives of resources. (2) Increase the SME ability to make variations of products. (3) Increase the ability of the SME to adopt 
new prodution methds.

Seventh meanwhile, To increase the innovation of the process of the SME, there are some efforts that can be done by business owners through any means of learning and coaching for increasing IKM craftsmen's skill on building a business strategy, such as: (1) increasing the ability to make innovation in administration. (2) Restructuring the organization into a more flexible one. (3) Increasing the craftsmen's ability in budget allocation and flexibility.

Eighth to researchers who are interested to conduct research with the same topic, the suggestions are: (1)To analyze other influential variables that have not been used in this research. (2) To account the financial statements in order to test the accuracy level to measure the work performance as this research is based on the perceptive analysis through ordinal data based-questionnaires.

\section{REFERENCES}

Agarwal.Sanjeev, Erramili. M. Krishna, \& Dev. S. Cekitan (2003). Market Oreintation and Performance in Service Firms : Role of Information. Journal of Service Marketing. Vol. 17, Issue : 1, pp. 68-82.

Atuahene-Gima, K. (1996). Market Orientation and Innovation. Journal of Business Research. 35 (2), 93-103.

Barnes, James G. (2000). Secrets of Customer Relationship Management: it's All About How You Make Them Feel. McGraw-Hill: New York.

Best, Roger. J. (2005). Market-Based Management : Strategies For Growing Customer value And Profitability. Fourth Edition. Pearson Prentice Hall.

Bharadwaj AS. (2000). A. Resource-Based Perspective on information technology capability and frm performance: an empirical investigastion. MIS Quartely 24 (1) : 169-196

Booth P. M. (1998), 'The Transition from Social
Jurnal Bisnis \& Manajemen, 2016, Vol. XVII, No. 1, 22-32

Insecurity'. Economic Affairs. 18(1)

Chris Barker, Nancy Pistrang \& Robert Elliot. (2002). Research Methods in Clinical Psychology. ( $2^{\text {nd }}$ ed.). John Wiley \& Sons, LTD Chichester England.

Churchill and lacobucci, (2005:79), Churchill. Gilbert A and lacobucci Dawn. (2005). Marketing Research: Methodological Foundation. Ninth Edition, Thomson South-Western.

Cooper, Donald R. \& Pamela S.Schindler. (2006). Business Research Methods. $9^{\text {th }}$ Ed. New York: McGraw Hill Companies.Inc.Mc.Kinsey \& Co, (2000:4).

Cravens, David W. \& Nigel F. Piercy, (2006). Strategic Marketing. $7^{\text {th }}$ Edition, McGraw-Hill, New York.

Fisk. Peter, (2006). Marketing Genius. John Wiley \& Sons. Hoboken.

George S. Day, Robin Wensley. (1988). "Assessing Advantage: A Framework for Diagnosing Competitive Superiority." Journal of Marketing 52 (April): 1-20.

Gray. Brendan J., Hooley. Graham J., (2002) Guest Editorial : Market Orientation and service firm performance - a reserach agenda. European Journal of Marketing. Vol. 36 Issued : 9/10, pp. 980-989.

Hee Sook Bae et al, (2001). Characteristic Predicates Selection and Semantic Constraint in Domain-Specific Corpus. KOTERM Symposium.

Hulth G.T.M., \& Ketchen Jr. D.J., (2001). “Does Market orientation Matter ? A test of Relationship Between Personal Advantage and Performance. Strategic Manegement Journal. 22(9). Pp. 899-906.

Jenny Hill, Patricia Tallack \& Hugh Garai of Echelon (1996). 30 Activities for Internal Customer Care. USA Gower. Vermont. 
Joreskog,K.G., \& Sorbom, D., (1996). “LISREL 8: User's Reference Guide. Scientific Sofware International. Inc., Chicago.

Koperasi Rajutan Binong Jati (2014).

Lado, Nora \& Albert Maydeu. (2000). Exploring The Link Between Market Orientation And Innovation In The Europan And US Inssurance Market. International Marketing Review. Vol 8. pp 130-144.

Low ,David R., Ross L. Chapman \& Terry R. Sloan. (2007). Inter-Relationships Between Innovation And Market Orientation In SMEs. Management Research News. Vol. 30 No. 12. pp. 878-891.

Michael E. Porter. (1985). The Competitive Advenatege : Creating and Sustaining Superior Performance. NY: Free Press.

Narver, J. C., \& Slater, S. F. (2000). The Positive Effect of a Market Orientation on Business Profitability: A Balanced Replication. Elsevier. 69-73.

Neely, A. and Adams, C. (2001), "The performance prism perspective". Journal of Cost
Management. Vol. 15 No. 1, pp. 7-15.

Stephen Brown, (1997). Marketing Science in a Postmodern World : Introduction to the Special Issue. European Journal of Marketing. Vo. 31, Issue : 3/4. pg. 167-182.

S pulendran, R Speed, RE Widding. (2000). The Antecendents and Consequences of Market Orientation in Australia. Australian Journal of Management. Vol. 25, No. 2, pp. 114143.

Sucherly. (1996). Strategi Pemasaran dalam Industri Kayu gergajian dan Pengaruhnya terhadap Penjualan. Disertasi. Universitas Padjadjaran. Bandung.

Thomas E. Powell, Anne Dent-Mecallef. (1997). Information Technology as competitive Advantage : The Role of Human, Business, and Technology resources. Strategic Management Journal. Vol. 18, Issue : 5, pp. 375-405.

William R George. (1990). Internal Marketing And Organizational Behavior: A Partnership In Developing Customer-Conscious Employees At Every Level. Journal of Business research. Vol. 20, Issue : 1, January 1990. Pp. 63-70. 